University of Nebraska - Lincoln

DigitalCommons@University of Nebraska - Lincoln

Faculty Publications, Department of Psychology

Psychology, Department of

$1-1-2003$

\title{
Adolescent Sexuality: Behavior and Meaning
}

Lisa J. Crockett

University of Nebraska-Lincoln, ecrockett1@unl.edu

Marcela Raffaelli

University of Nebraska-Lincoln, mraffaelli1@unl.edu

Kristin L. Moilanen

University of Nebraska-Lincoln, klmoilanen@mail.wvu.edu

Follow this and additional works at: https://digitalcommons.unl.edu/psychfacpub

Part of the Psychiatry and Psychology Commons

Crockett, Lisa J.; Raffaelli, Marcela; and Moilanen, Kristin L., "Adolescent Sexuality: Behavior and Meaning" (2003). Faculty Publications, Department of Psychology. 245.

https://digitalcommons.unl.edu/psychfacpub/245

This Article is brought to you for free and open access by the Psychology, Department of at DigitalCommons@University of Nebraska - Lincoln. It has been accepted for inclusion in Faculty Publications, Department of Psychology by an authorized administrator of DigitalCommons@University of Nebraska - Lincoln. 


\title{
Adolescent Sexuality: Behavior and Meaning
}

\author{
Lisa J. Crockett, Marcela Raffaelli, and Kristin L. Moilanen \\ University of Nebraska-Lincoln
}

\section{Introduction}

The emerging sexuality that accompanies adolescence poses fundamental challenges for young people. These include adjusting to the altered appearance and functioning of a sexually maturing body, learning to deal with sexual desires, confronting sexual attitudes and values, experimenting with sexual behaviors, and integrating these feelings, attitudes, and experiences into a developing sense of self. The challenge is accentuated by the unfamiliar excitement of sexual arousal, the attention connected to being sexually attractive, and the new level of physical intimacy and psychological vulnerability created by sexual encounters.

Adolescents' responses to these challenges are profoundly influenced by the social and cultural context in which they live. In the United States, in contrast to many other Western nations, adolescent sexuality has typically been viewed as inappropriate and troublesome rather than as normal and healthy. In part, this reflects cultural mores about nonmarital sexual activity; in part it reflects well-justified concerns about potential negative consequences of sexual activity (see chapters 20 and 27 in this volume). Cultural proscriptions against nonmarital sex are counterbalanced by permissive attitudes reflected in the media and in the values of many adults. These competing perspectives co-mingle, creating a situation where adolescents are exposed to sexual material in settings of daily life but given inadequate preparation to behave responsibly in sexual situations. Feelings of sexual desire and love collide with social prescriptions to show restraint, setting the stage for psychological conflict and behavioral inconsistency.

Despite a recognition of the subjective aspects of adolescent sexuality, the scientific literature has focused primarily on objective indicators such as having sex at certain ages, the behaviors adolescents practice, and the health-related outcomes of teen sexual activity (Moore $\&$ Rosenthal, 1993). While this approach helps define the scope 
of the "problem," it fails to address the intrapsychic and interpersonal processes that influence whether intercourse occurs and whether protection is used. Understanding these subjective dimensions is key to developing effective interventions to reduce risky sexual behavior; it is also critical for grasping the meaning young people ascribe to their experiences, and the ways in which sexuality is integrated into their identities and intimate relationships (e.g., Brooks-Gunn \& Paikoff, 1997).

To provide an integrated picture of adolescent sexuality, we address three related issues: (1) recent trends in sexual behaviors among US adolescents; (2) individual and social factors influencing adolescent sexual behavior; and (3) how adolescents make sense of their sexual feelings and experiences. We highlight variations related to gender and ethnicity, but our scope is limited to heterosexual behavior (for a discussion of gay and lesbian youth, see chapter 19 in this volume). Wherever possible, we rely on recent national surveys for information on the attitudes and experiences of contemporary youth.

\section{Sexual Behaviors}

Both sexual ideation and activity increase over the adolescent period (e.g., Halpern et al., 1993). Teenagers engage in a spectrum of sexual behaviors ranging from fantasy and self-stimulation to various forms of intercourse.

\section{Non-coital sexual behaviors}

Fantasy. Erotic fantasy is the most common sexual behavior in adolescence. In a nonrepresentative sample of 13-18-year-olds, 72 percent acknowledged having sexual fantasies (Coles \& Stokes, 1985). Erotic fantasies serve several important functions for adolescents: along with creating pleasant sexual arousal and expressing sexual needs, they provide insight into sexual desires and preferences and are an opportunity to "rehearse" sexual encounters (Katchadourian, 1990).

Masturbation. Similar to fantasy, masturbation allows teenagers to explore their sexuality in a safe and private way, and is generally regarded as a normative activity (Katchadourian, 1990). In one survey, 46 percent of boys and 24 percent of girls reported masturbating (Coles \& Stokes, 1985); among college students, 67 percent of males and 34 percent of females reported masturbating at age 15 (Leitenberg, Detzer, \& Srebnik, 1993). However, masturbation remains a taboo topic in the United States. This taboo is apparent in a content analysis of sex-related items published in Seventeen magazine: masturbation was not mentioned at all in 1974 and appeared in less than 5 percent of items in 1984 and 1994 (Carpenter, 1998).

"Making out." Most US adolescents-engage in physically intimate behavior, even if they do not have intercourse. In a sample of ethnic minority 14-17-year-olds who had not yet had intercourse, 86 percent had kissed, 47 percent had rubbed their body against another, and 16 percent had engaged in genital touching (K. Miller et al., 1997). In a multiethnic sample of 12-15-year-olds, Smith and Udry (1985) 
found that white adolescents followed a typical progression from necking, to petting above the waist, to genital touching, to intercourse. A similar sequence emerged in a primarily white. Mormon sample (B. Miller et al., 1998). In contrast, black adolescents showed no predictable sequence of sexual behaviors, and many reported intercourse prior to heavy petting (Smith \& Udry, 1985). Thus, the timing and sequencing of sexual behaviors appear to differ for blacks and whites.

\section{Sexual intercourse}

The majority of US adolescents experience intercourse by age 18. In recent national surveys, 50 percent of 9th-12th-graders reported they had had sex (Blum et al., 2000; CDC, 2000). The likelihood of intercourse increases with age, so that by 12th grade, approximately two-thirds of students have had sex (CDC, 2000). This is likely an underestimate, as school-based surveys exclude high school dropouts and youth enrolled in alternative schools, who are more likely to be sexually active.

The prevalence of adolescent intercourse differs by race and ethnicity. Among participants in the National Survey of Adolescent Health (Add Health), less than half of white (46 percent) and Hispanic (47 percent) high school students reported sexual intercourse, compared to two-thirds (67 percent) of blacks (Blum et al., 2000). Similarly, in 1995. 88 percent of black males aged 17-19 reported engaging in sex, compared to 64 percent of non-black males (Ku et al., 1998). Among females aged 15-19 in 1995, 60 percent of non-Hispanic blacks, 56 percent of Hispanics, and 51 percent of non-Hispanic whites reported intercourse (Singh \& Darroch, 1999). Boys tend to initiate intercourse earlier than girls: in 1999, 45 percent of 9th-grade boys but 33 percent of 9th-grade girls reported intercourse (CDC, 2000).

Historical trends. Decreases in the age of pubertal onset over the twentieth century, combined with an increase in the age of marriage in recent decades, has resulted in a span of over ten years between sexual maturity and marriage (Brooks-Gunn \& Paikoff, 1997). This extended interval makes premarital sex likely. Historical data on premarital intercourse indicate that adolescent sexual activity increased during the twentieth century, especially for white females. By 1979, about half of white high school seniors of each gender reported having sex (Chilman, 1986). Although rates of sexual activity among teenagers appear to have leveled off, recent data show a continued trend towards earlier ages at first intercourse among adolescents who do initiate sexual activity. In 1995, 19 percent of teenage girls engaged in sex before age 15, almost double the proportion in 1988 (Child Trends, 2000).

Partners. Two-thirds of girls and half of boys aged 14-18 report having fewer than two sexual partners in their lifetime (CDC, 1992; cited in Santelli et al., 1998). However, 13 percent of high school girls and 19 percent of high school boys report having four or more lifetime partners (CDC, 2000). Among sexually active adolescents, older youth are more likely to have multiple partners: 21 percent of 12th-graders compared to 12 percent of 9th-graders reported four or more partners (CDC, 
2000). Thus, although most adolescents engage in serial monogamy, because their relationships are often short-lived, they may have several partners over time (see Moore \& Rosenthal, 1993 for a discussion).

Sexual coercion. Not all sexual intercourse is voluntary, particularly for girls. Among 17-23-year-old female participants in the National Survey of Children, 7 percent had been "forced to have sex against [their] will or raped" at least once (Miller, Monson, \& Norton, 1995). Similarly, the 1995 National Survey of Family Growth indicated that among 15-19-year-old girls who have had sex, 7 percent said their first intercourse was nonvoluntary and another 24 percent said it had been voluntary but unwanted. Rates of sexual coercion were especially high among girls who initiated sex before age 13: one-fifth said their first intercourse was non-voluntary and another half said it was voluntary but unwanted (SIECUS, 1997).

In sum, research since the 1980s has yielded a wealth of data about certain aspects of adolescent sexual behavior, particularly intercourse. About two-thirds of US teens experience first sexual intercourse by 12 th grade; thus, initiating intercourse is a normative experience for teenagers. Next, we turn to an examination of biological, psychological, and sociocultural factors that influence adolescent sexual behavior.

\section{Biological Influences}

\section{Puberty}

Puberty encompasses dramatic changes in hormone levels, body shape, and physical size (see chapter 2 in this volume). Research has linked both stage of pubertal development and timing of puberty to adolescent sexual behavior. Among 7thand 8th-grade boys, pubertal development over a six-month period was associated with concurrent changes in sexual ideation and precoital behavior, and pubertal stage predicted the transition to intercourse (Halpern et al., 1993). Among girls, pubertal stage predicted level of sexual experience the following year (Whitbeck, Conger, \& Kao, 1993). For both genders, earlier pubertal onset relative to peers was associated with greater sexual experience (Flannery, Rowe, \& Gulley, 1993; B. Miller et al., 1998). Among girls, early menarche was associated with a younger age at first intercourse (Magnusson, 1988; B. Miller et al., 1997); among boys, advanced pubertal maturation relative to peers was associated with earlier first intercourse (Capaldi, Crosby, \& Stoolmiller, 1996).

Pubertal hormones may underlie the relation between pubertal development and sexual behavior. Testosterone administration increases sexual interest and behavior in women (Sherwin, Gelfand, \& Brender, 1985) and in men with low testosterone levels (Kwan et al., 1983). Similarly, cross-sectional studies by Udry and colleagues demonstrated an association between androgen levels and both sexual motivation and behavior in early adolescence (Udry et al., 1985; Udry, Talbert, \& Morris, 1986). However, longitudinal studies have not supported this linkage: increases in testosterone over early adolescence failed to predict changes in sexual behavior for either gen- 
der (Udry \& Campbell, 1994). Among boys, initial testosterone levels were associated with concurrent and subsequent sexual behavior, but changes in testosterone did not predict changes in sexual ideation or behavior (Halpern et al., 1993). Among postmenarcheal girls, pubertal development significantly predicted non-coital behavior and intercourse, but testosterone levels did not (Udry \& Campbell, 1994). Thus, rather than exerting a direct influence on sexual behavior, hormones may operate indirectly by stimulating physical maturation and sexual attractiveness.

\section{Genetic factors}

Age of puberty is partly inherited, providing a potential genetic basis for individual differences in the timing of first intercourse. Evidence of heritability is found in high intercorrelations in age at menarche between mothers and daughters and between sisters (Garn, 1980). Genetic effects are also implicated by the recent finding that dopamine receptor genes are associated with age of first intercourse (W. Miller et al., 1999). However, mother's age at menarche does not necessarily predict early initiation of intercourse by her children (Mott et al., 1996), so other mechanisms are likely involved.

\section{Biosocial models}

Recent models of adolescent sexual behavior incorporate both biological and social influences (e.g., Irwin et al., 1997). For example, Smith, Udry, and Morris (1985) found that pubertal indices and best friends sexual behavior each predicted the sexual behavior of boys and girls; among girls, the impact of friend's sexual behavior was particularly pronounced at advanced stages of pubertal development. B. Miller et al. (1998) found direct effects of pubertal development for both genders, along with an indirect effect of parent-child communication about sex on girls' level of sexual experience two years later. These studies underscore the need to consider social as well as biological influences.

\section{Sociocultural Influences}

Human societies differ greatly in the cultural rules regulating sexual behavior and the vigor with which they are enforced. In some cultures premarital sex is encouraged because pregnancy allows a determination of the fertility of potential marriage partners; in other cultures premarital sex is strongly discouraged, especially for girls, because virginity is highly prized (Paige \& Paige, 1985; Whiting, Burbank, \& Ratner, 1986). The United States is an interesting case because of its ambivalent treatment of adolescent sexuality. Despite increased societal permissiveness since the 1950s (Chilman, 1986) and the fact that the majority of adolescents have sex, many adults are reluctant to accept adolescent intercourse. Whereas only a fourth of US adults in the early 1990s disapproved of premarital sex in general, two-thirds said that sex between adolescents was wrong (Smith, 1994). Because of these negative attitudes, adolescents, who are encour- 
aged to prepare for adulthood in many arenas (e.g., by studying or getting a job), are given little guidance and training for sexual experimentation. The "abstinence-only" movement in sexuality education is a prime example of this neglect.

In regard to sexuality education, the contrast between the United States and other Western countries is striking. For example, the Swedish State Commission on Sex Education suggests that students should gain knowledge that "will equip them to experience sexual life as a source of happiness and joy in fellowship with other[s]" (Brown, 1983, p. 880, cited in Fine, 1988). In contrast, US sex education curricula have typically focused on the dangers of sex and on girls' need for protection from predatory males (Fine, 1988); more recently, federal mandates for "abstinence-only education" have further narrowed opportunities for federally funded programs to discuss the full range of sexual experiences and feelings. However, the former Surgeon Generals call to action to promote sexual health and responsible sexual behavior suggests a renewed interest in open dialogue about sexuality (Satcher, 2001).

Cultural values and attitudes regarding sexuality are distilled through experiences in everyday social contexts. Interactions within families, peer groups, and other daily contexts can influence whether and when an adolescent will initiate sexual intercourse.

\section{Family influences}

Family processes. Parent-child relationships, parental control, and parent-child communication have all been implicated in adolescent sexual behavior. Better parent-child relationships are associated with postponing intercourse, less frequent intercourse and fewer sexual partners (for a review, see Miller, Benson, \& Galbraith, 2001). Although most studies are cross-sectional, similar relations have been found longitudinally (Feldman \& Brown, 1993; K. Miller et al., 1998.) Effects of motherchild relationship quality have emerged for both sons and daughters (Jaccard, Dittus, \& Gordon, 1996; Weinstein \& Thornton, 1989), and the quality of the father-child relationship is influential for boys (Feldman \& Brown, 1993). Effects of parent-child closeness have been found among blacks and whites and in multiethnic samples (Dittus \& Jaccard, 2000).

Several mechanisms may underlie the associations between family relationships and adolescent sexual activity. Poor parent-child relationships may enhance susceptibility to peer influences or increase the propensity to associate with deviant friends (Whitbeck, Conger, \& Kao, 1993). Mechanisms may differ for girls and boys: Whitbeck and colleagues found that, for girls, the relation between low parental warmth and sexual behavior was mediated by depressed mood, whereas for boys it operated through alcohol use (Whitbeck et al., 1992). In a study of boys, those from families characterized by low support, high indulgence, and paternal rejection had lower self-restraint and more sexual partners (Feldman \& Brown, 1993). Such mediating variables may explain why parent-child relationship quality does not always have significant effects on adolescents' sexual behavior when examined within multivariate models (Crockett et al., 1996; Small \& Luster, 1994). 
Parental control is also related to adolescent sexual activity. Typically, better monitoring is associated with postponing intercourse (Jacobson \& Crockett, 2000) or less frequent intercourse (Benda \& DiBlasio, 1994), although not all studies find this pattern (e.g., East 1996). Presumably, parental monitoring and supervision reduce adolescent intercourse by restricting opportunities for sexual activity; however, some studies indicate that sexual activity is more likely when parental control is excessive (Miller et al., 1986) or intrusive (Upchurch et al., 1999).

Direct communication is another way in which parents may influence their children's sexual behavior. However, family communication about sex is infrequent (Raffaelli, Bogenschneider, \& Flood, 1998), and parents and teens often disagree about the frequency and content of these conversations (Jaccard, Dittus, \& Gordon, 1998). Research on parent-adolescent communication and adolescent sexual activity has yielded complex and often contradictory findings. The impact of parent-child communication appears to depend on openness of the communication, a clear focus on sexual topics, the quality of the parent-child relationship, and the parents values regarding adolescent sexual activity (see Miller, Benson, \& Galbraith, 2001).

Parents' attitudes about adolescent sex predict their children's sexual attitudes and behavior (Thornton \& Camburn, 1989; Treboux \& Busch-Rossnagel, 1990). Moreover, adolescents' perceptions of parental disapproval of sex are associated with postponing intercourse (Jaccard, Dittus, \& Gordon, 1996; Sieving, NcNeely, \& Blum, 2000). These effects are enhanced when the parent-child relationship is close, indicating that values are more easily transmitted within supportive parent-child relationships (Dittus \& Jaccard, 2000; Weinstein \& Thornton, 1989).

Family composition and socioeconomic status. Consistent associations have been found between family structure (especially living in a single-parent family) and earlier first intercourse (B. Miller et al., 1997). This effect persists after controlling for demographic variables such as race, social class, and age. It has been attributed to modeling (Miller \& Bingham, 1989), permissive parental attitudes (Thornton \& Camburn, 1987), and reduced parental control (Newcomer \& Udry, 1987). Single parents who date may be salient role models. In a study of recently divorced mothers and their adolescent children, maternal dating had a direct positive relation to sons' level of sexual experience; for daughters, the effect was mediated by girls' permissive sexual attitudes (Whitbeck, Simons, \& Kao, 1994).

The sexual behavior of family members is also associated with adolescent sexual activity. Teenagers whose mothers initiated sex and childbearing at younger ages are more likely to have sex (Kowaleski-Jones \& Mott, 1998) and to experience early sexual debut (Ku, Sonenstein, \& Pleck, 1993a). Moreover, the presence of older sexually active siblings, especially teenage sisters who are pregnant or parenting, is related to younger siblings' sexual experience, earlier first intercourse, and pregnancy risk (East, Felice, \& Morgan, 1993; Widmer, 1997). These associations could reflect modeling effects but may also be genetically mediated through early timing of puberty (Newcomer \& Udry, 1984). 
Finally, consistent associations have been found between family socioeconomic status and adolescent sexual activity. Lower family income (Upchurch et al., 1999) and lower parental educational attainment (Brewster, 1994; Sieving, McNeely, \& Blum, 2000) are associated with a greater likelihood of teenage intercourse. These associations may reflect differences in perceived life opportunities and available social roles.

\section{Peer influences}

Peers are presumed to exert a major social influence on adolescent sexual behavior. Peer effects may operate at several levels. Same-sex peers are a major source of information about sex (Davis \& Harris, 1982), and peers provide settings (e.g., cars, parties) where sex can occur (Rowe \& Linver, 1995). Same-sex friends may influence the perceived acceptability of sexual behavior, and sexually experienced friends may serve as role models. Finally, romantic partners provide opportunities for sexual experimentation and may also exert pressure for sex (Wyatt \& Riederle, 1994).

Friends. Associations between close friends' sexual behavior are well documented (East, Felice \& Morgan, 1993; Rodgers \& Rowe, 1990; Whitbeck et al., 1993). Although these patterns could indicate a peer socialization effect, selection may also play a role, if adolescents choose friends who are like themselves in attitudes and behavior (Bauman \& Ennett, 1996; Billy, Rodgers, \& Udry, 1984). In a longitudinal study, best friends' sexual experience was strongly associated with the initiation of intercourse for white females, but for white males the association appeared to reflect boys' selection of friends with levels of sexual experience similar to their own. No evidence of peer influence was found for blacks of either gender (Billy \& Udry, 1985).

Associating with deviant peers has been linked to earlier initiation of intercourse (Rowe et al., 1989a; Whitbeck et al., 1999). Conversely, spending time with conventional peers in extracurricular activities is negatively associated with adolescent intercourse (Miller \& Sneesby, 1988).

Jaccard, Blanton, and Dodge (2000) attempted to isolate peer socialization effects by controlling for potential confounds related to inaccurate reporting of friends' behavior, selection of friends, and common experiences (e.g., similar rate of pubertal development). Once statistical controls were applied, peer effects were small and occurred only between friends with similar sexual experience. Thus, effects of peer behavior may be limited; beliefs about friends' sexual behavior appear more influential than friends' actual behavior (Cvetkovich \& Grote, 1980).

Romantic partners. Most teenagers become involved in romantic relationships (see chapter 15 in this volume). The proportion of Add Health respondents reporting a "serious romantic relationship" in the past 18 months increased from one-third of 13 -year-olds to over half of 15 -year-olds, to 70 percent of 17 -year-olds (Raffaelli, unpublished analysis). Romantic or dating relationships often provide the context for adolescent sexual behavior. Early and steady dating predict sexual behavior for both genders (Miller et al., 1986; B. Miller et al., 1997; Thornton, 1990). Among adoles- 
cents in the Add Health study, being in a romantic relationship increased the likelihood of sexual activity (Dittus \& Jaccard, 2000). Finally, three-quarters of female National Survey of Family Growth (NSFG) participants aged 25 and under who had their first voluntary sexual intercourse before age 18 said they were "going steady" (73.9 percent) with or engaged to (1.9 percent) their first sexual partner" (Manning, Longmore, \& Giordano, 2000).

\section{Neighborhood influences}

Neighborhoods can be a source of models for and information about sexual behavior. Living in poor neighborhoods is associated with greater frequency of intercourse among males (Ku, Sonenstein, \& Pleck, 1993b) and with higher rates of adolescent pregnancy (Hogan \& Kitagawa, 1985). Community variables, such the percentage of women working full time, are negatively associated with rates of premarital intercourse for both black and white women (Billy, Brewster, \& Grady, 1994) and help account for racial disparities in timing of first intercourse (Brewster, 1994). The proportion of middle-class neighbors is negatively associated with adolescent childbearing, whereas the prevalence of female-headed families is a positive predictor. These neighborhood "effects" may reflect the role models available to youth and the potential for collective monitoring by adults (Brooks-Gunn et al., 1993).

\section{Media}

Adolescents are frequently exposed to sexual material on television, in movies, and in magazines. Most sexual behavior on television takes places between unmarried adults and ignores the potential negative consequences of sexual intercourse; music videos often combine sex and violence (Huston, Wartella, \&: Donnerstein, 1998). However, the effect of media exposure on adolescents' sexual attitudes and behavior has not been sufficiently studied. Experimental studies show that exposure to sexual content can lead to more permissive attitudes about premarital sex, but a link between exposure and adolescent intercourse has not been established (Huston, Wartella, \& Donnerstein, 1998).

\section{Psychological and Behavioral Influences}

\section{Attitudes and values}

Adolescents' attitudes about sex are shaped by family values and cultural proscriptions as well as personal experience. In 1967, Reiss argued that most adolescents subscribed to the notion that sexual intimacy was permissible in the context of affection (Reiss, 1967). Most 18-25-year-olds continue to approve of premarital sex under some conditions; less than 20 percent say premarital sex is always wrong (Smith, 1994). Nonetheless, there is considerable variability in adolescents' opinions about the appropriateness of premarital sex, especially casual sex. More permissive 
attitudes about sex predict adolescents' level of coital and precoital experience and their initiation of intercourse (Treboux \& Busch-Rossnagel, 1990; Whitbeck et al., 1999). Young men hold more permissive sexual attitudes than young women (Feldman, Turner \& Araujo, 1999).

Religion is often linked to adolescent sexual behavior (see Rostosky et al., in press, for a review). Youth who have no religious affiliation are most likely to initiate sex as teenagers (Forste \& Heaton, 1988), and those who belong to churches that promote abstinence are least likely to have sex (e.g., Miller \& Olson, 1988). Greater religiosity, as indexed by frequency of church attendance and perceived importance of religion, is associated with postponing intercourse (Cvetkovich \& Grote, 1980; Jessor et al., 1983; Thornton \& Camburn, 1989; Whitbeck et al., 1999). In a national sample, greater frequency of attending religious services decreased the odds of initiating intercourse among white males and white, Latina, and black women (Day, 1992).

\section{Academic achievement and educational investment}

Adolescents with higher educational aspirations and better academic performance tend to postpone first intercourse (Jessor et al., 1983; Miller \& Sneesby, 1988) and have sex less often (Ohannessian \& Crockett, 1993). Time spent in academic activities is also negatively related to early intercourse, especially for girls (Crockett et al., 1996; Whitbeck et al., 1999).

\section{Psychosocial adjustment}

Psychological well-being. Although low self-esteem has been proposed as a predictor of early intercourse, evidence of this relationship is weak. In longitudinal studies, the association is weak or nonsignificant (Crockett et al., 1996; Jessor et al., 1983; Whitbeck et al., 1999). A more robust effect has been found for depression: depressed affect is positively associated with girls' sexual experience (Whitbeck et al., 1992, 1993, 1999).

Problem behaviors. Consistent linkages have been found between early sexual activity and other forms of misconduct, including delinquent activities (Costa et al., 1995; Ketterlinus et al., 1992), substance use (Halpern-Felsher, Millstein, \& Ellen, 1996), and such behaviors as cheating on tests (Rodgers \& Rowe, 1990). Some scholars have suggested that the association among problem behaviors reflects a common deviance trait (Rowe et al., 1989b) or a personality disposition towards unconventionality (Costa et al., 1995). It could also represent an emerging lifestyle or pattern of adaptation. Bingham and Crockett (1996) found that adolescents who experienced early, middle, and late sexual debut exhibited distinct developmental trajectories, with those who initiated sex early showing a longitudinal pattern of poorer adjustment in multiple domains, including academic achievement, family relationships, and misconduct. 


\section{Risk tolerance and self-restraint}

Adolescent sexual activity may also be linked to a general propensity to engage in potentially risky activities. Risk-proneness and involvement in problem behaviors predicted nonvirginity in both genders (Kowaleski-Jones \& Mott, 1998). Among boys, self-restraint at ages 10-11 was inversely associated with number of sexual partners and level of misconduct four years later (Feldman \& Brown, 1993). Finally, in a clinic sample, girls terminating a pregnancy were found to be more impulsive than those seeking contraceptive advice (Rawlings, Boldero, \& Wiseman, 1995).

\section{Making Sense of Sexuality}

Adolescents must sort out what they believe about sexuality, just as they must grapple with other aspects of their personal identity. However, relatively little research exists on adolescents' constructions of sexuality. Their view of sex and the meaning it holds are likely based on internalized cultural images of sex and romance as well as on their own experiences of love and desire. These subjective elements, along with situational factors that affect decision making, play an important role in sexual choices and behavior. In the following paragraphs we review the meager literature on these issues.

\section{Cultural templates}

Long before adolescents actually engage in sexual intercourse, they have developed a complex set of ideas about sexuality and sexual encounters. Some theorists describe these mental representations as "scripts" that provide guidelines for heterosexual interactions (Gagnon, 1973, 1990). In fact, college students agree on how men and women should behave on a first date (Rose \& Frieze, 1993), and adolescents agree about what behavior is appropriate at different ages. For example, Australian girls and boys tend to agree that kissing should occur at ages 12-14 and fondling, intercourse, and oral sex at ages 15-17 (Rosenthal \& Smith, 1997). US college students endorse a similar sexual timetable (Feldman, Turner, \& Araujo, 1999). Given the historical double standard, scripts for female sexuality have changed more in recent decades than scripts for male sexuality (Thompson, 1995). An examination of sexual discourse in Seventeen magazine from the 1970s to the 1990s revealed that young women went from being portrayed as sexual objects to being acknowledged as sexual agents (Carpenter, 1998). Nevertheless, later issues presented contradictory messages about sexuality, emphasizing victimization as well as choice, and morality as well as desire.

Despite a gender convergence in sexual behaviors, a double standard remained in the late 1980s such that girls were judged more harshly than boys for engaging in some types of sexual activities (Moore \& Rosenthal, 1993). In qualitative interviews, girls were more likely than boys to express ambivalence about their sexuality and to be concerned about how they would be viewed if they were sexually active (Hillier, Harrison, \& Warr, 1997). This concern is well founded, as girls who have multi- 
ple sexual partners still risk being labeled "sluts" (Orenstein, 1994, cited in Graber, Brooks-Gunn, \& Galen, 1998).

\section{Constructions of love, desire, and sexual identity}

Love. Although adults often discount adolescent relationships as "puppy love," the feelings associated with "crushes" and romantic relationships can be intense (see chapter 15 in this volume). Romantic feelings emerge at an early age. In one study, 7th- and 8thgraders spent 4-6 hours a week thinking about individuals of the other sex (Richards et al., 1998). Among 7th-12th-graders, being with someone of the other sex was associated with more positive moods and more frequent feelings of being "in love" compared to other social contexts (Richards et al., 1998). Romantic feelings have been linked to pubertal development. Feelings of being "in love" were associated with self-rated changes in body shape among 5th-9th-grade girls and with pubic hair growth among 5thand 6th-grade boys (Richards \& Larson, 1993). Importantly, feelings of love can affect sexual decision-making. As one girl stated, "When you're there with him and you love him so much, it's hard to say no" (Public Policy Productions, 1995).

Desire. Little is known about adolescents' experience of sexual desire. Of necessity, studies of adolescents' sexual feelings have been conducted with convenience samples, limiting their generalizability. Nonetheless, they provide important information about how adolescents make sense of their emerging sexuality. In general, males more often emphasize physical aspects of sex (e.g., satisfaction, release) whereas females emphasize emotional aspects such as love and intimacy (Moore \& Rosenthal, 1993). However, recent research with adolescent girls reveals myriad perspectives about the connection between sex and love. Thompson (1995, p. 14) identified "girls who strove desperately to fuse sex and love ... girls who preferred playing the field to pursuing steady love ... girls who chose ... to value work over love; girls who declined the right to separate sex and reproduction."

Similarly, in an analysis of discourses on sex, relationships, and reproduction (Lamanna, 1999), a third of young women (35 percent) emphasized sex avoidance and another third (35 percent) situated sex and reproduction in the context of a relationship characterized by love, caring, and domesticity. The remaining women characterized their sexual activity as lacking intentionality - something that "just happens" (16 percent) or as an act of self-development (14 percent).

Life circumstances may influence these diverse perspectives. Tolman and Szalacha (1999) analyzed the "narratives of desire" among 15-19-year-old girls attending a suburban (primarily white) school or an urban (largely minority) school. Almost half the narratives focused on vulnerability, 29 percent on pleasure, and 24 percent on a mix of themes. Urban girls told more narratives about vulnerability than pleasure, whereas suburban girls generated equal numbers of narratives on these two themes, unless they had experienced sexual violation. Only suburban girls who had not experienced violation talked about desire in a way that suggested a healthy "embodied sexuality" (Hillier, Harrison, \& Bowditch, 1999): "Both sexual desire and sexu- 
al pleasure are known to them as profoundly physical experiences—as feelings they perceive in their own bodies" (Tolman \& Szalacha, 1999, p. 29). In contrast, urban girls and suburban girls who had been violated talked about their sexual experiences in a disconnected way.

Sexual identity. Ultimately, adolescents must develop a concept of themselves as sexual beings and integrate their sexual self into their overall identity. This process begins when young people first recognize their feelings of sexual arousal and may continue throughout life (Graber, Brooks-Gunn, \& Galen, 1998). Key dimensions of the sexual self-concept may include sexual self-esteem, sexual self-efficacy/mastery, and beliefs about sexual self-image. Buzwell and Rosenthal (1996) identified five sexual styles among Australian adolescents: sexually naive, sexually unassured, sexually competent, sexually adventurous, and sexually driven. The clusters differed in gender, age composition, and sexual history (e.g., the sexually naive group contained more girls, virgins, and younger students). Notably, the five clusters also differed in their patterns of sexual risk-taking, suggesting the utility of this classification scheme in understanding how sexual self-concept might affect adolescents' behavior.

\section{Situations of sexual possibility}

Although sexual identity and sexual motives influence adolescents' decisions about whether to have sex, situational variables also play a role. Boys and girls in the United States have opportunities to be together in private, affording them what Roberta Paikoff (1995) has called "situations of sexual possibility." Opportunities for privacy increase with age. In one study, the amount of time adolescents spent alone with a person of the other sex increased from under three hours a week in 9th grade to over eight hours in 12th grade (Richards et al., 1998). When sexual opportunities occur, attitudes about sex and feelings about the partner influence whether intercourse occurs; furthermore, attitudes toward contraception and the ability to plan ahead influence whether sex is unprotected. However, other variables also enter into the equation. For many adolescents sex is sporadic and thus hard to predict. Moreover, some adolescents have ambivalent feelings about preparing for sex, even when they think it might occur. For example, girls may be concerned that they will appear "loose" if they carry condoms (Hillier, Harrison, \& Warr, 1997). Thus, for various reasons adolescents may be unprepared for a sexual encounter.

We must also consider the effects of intense desire on the behavior of adolescents who have not let learned to control their emotions. Although adolescents demonstrate sound decision-making skills in laboratory settings, real-life decision making occurs under nonoptimal conditions, such as time pressure (Keating, 1990). Hamburg (1986) has suggested that sexual decision-making reflects "hot cognitions" as opposed to "cold cognitions," and may be less reasoned and logical. The use of alcohol or other drugs also affects judgment in sexual situations.

Additionally, some adolescents engage in sex for reasons other than desire. Parents of poor, urban, African American adolescents speculate that their teenagers have sex 
in exchange for protection from gangs and because they routinely witness sexual activity among older peers in their buildings (Brooks-Gunn \& Paikoff, 1997). Sprecher and McKinney (1987) suggest that sex can represent an act of exchange, interdependence, maintenance, self-disclosure, intimacy, or love. Curiosity and pressure from peers and partners also plays a role in early sexual encounters (Wyatt \& Riederle, 1994). What happens in situations of sexual possibility depends on the myriad functions sex can serve and the salience of these functions to the young people involved.

Finally, it is critical to recognize that there are two people involved in a sexual encounter. Thus, two people's desires, attitudes, and intentions need to be taken into account in predicting sexual behavior. Moreover, the partners likely differ in power, making one partner's wishes more influential (Fine, 1988; Hillier, Harrison, \& Warr, 1997). Partners who are aware of the power differential perceive that they have more or less control in the situation; adolescents who perceive little control may not assert their wishes. In a study of Australian adolescents, two-thirds reported that they talked about condoms the last time they had sex, yet almost one-fifth of these youth did not use a condom (Hillier, Harrison, \& Warr, 1997). Thus, sexual communication between partners does not guarantee better decision-making.

\section{Conclusions and Directions for Future Research}

Research on adolescent sexuality has tended to be behavior-focused, spurred by concerns about adolescent pregnancy and health risks. Such a focus affords only a partial understanding of adolescent sexuality, neglecting the subjective and interpersonal dimensions that provide the psychological context for sex. Thus, we know much about adolescents' sexual behavior, especially intercourse, but little about their reasons for having sex or the meaning they ascribe to their behavior.

Studies of adolescent sexual behavior have moved beyond identifying individual predictors of sexual activity to testing multivariate models that incorporate biological, psychological, and social factors (e.g., Crockett et al., 1996; Udry \& Billy, 1987). However, most studies still focus on intercourse, rather than other forms of sexual expression that precede or co-occur with intercourse. Moreover, many studies of intercourse do not distinguish between vaginal, oral, and anal sex. Finally, most studies conceptualize intercourse dichotomously, as having occurred or not occurred. Fortunately, more sophisticated approaches are beginning to appear in the literature. Kim Miller and colleagues (1997) identified two subgroups of virgins in their white heterosexual sample: "delayers" had never engaged in intercourse and did not think they would in the next year, whereas "anticipators" reported a high likelihood of sexual initiation in the next year. Significant differences in non-coital experiences (kissing and genital touching) emerged between "anticipators" and "delayers" who would normally be pooled into a "not sexually active" group. Similarly, Luster and Small (1994) classified their sample of adolescents into high-risk youth (more than one lifetime sex partner and infrequent or no contraceptive use); low-risk youth (one partner and al- 
ways used contraception); and abstainers. Significant differences emerged among the groups. ${ }^{2}$ The differentiated approach exemplified in these typologies should lead to a more nuanced understanding of adolescent sexual behavior in future years.

Studies of sexual behavior and the determinants of sexual activity have revealed important differences related to gender, race/ethnicity, and socioeconomic status, but these variables have not been fully examined in studies of subjective aspects of sexuality. Attention has focused mainly on girls; thus, little is known about boys' experiences of sexuality. The picture that emerges from the scant literature is largely negative; boys come across as manipulators who will do anything to "get sex" and avoid emotional entanglements. The reality is more complicated, but only a handful of studies on boys' subjective experiences of sexuality have been conducted (e.g.. Fine, 1987). Regarding ethnicity, the work of Tolman and her colleagues (e.g., Tolman \& Szalacha, 1999) reveals important differences in how girls from suburban (mostly white) and urban (mostly minority) schools conceptualize their feelings of desire. However, additional research is needed to disentangle differences due to ethnicity from those due to location (urban vs. suburban), and to uncover the processes that produce these differences.

Although sexual activity typically involves two people who may have differing levels of arousal, distinct emotions and desires, and different levels of power, relatively little attention has been paid to adolescents' sexual partners, and most research has obtained data from only one member of the couple. Past research has shown the importance of relationship characteristics in influencing contraceptive use at first intercourse (Manning, Longmore, \& Giordano, 2000); for example, female NSFG respondents younger than 18 whose partners were six or more years older were less likely to report contraceptive use at last intercourse than young women whose partners were within two years of their age; they were also more likely to become pregnant and bear a child (Darroch, Landry, \& Oslak, 1999). Future research should examine the role of partners more fully.

There is an ongoing need for longitudinal research that tracks changes in attitudes, behaviors, and subjective experience over time. This is especially critical for building a picture of how sexual self-concept develops and how sexuality becomes integrated into the young person's identity and construction of relationships. Unfortunately, considerable challenges remain to conducting such studies, given the moral climate that persists in the United States. Until we accept adolescent sexuality, we will be unable to protect young people from potential negative consequences and foster their healthy sexual development.

\section{Notes}

1. 21.3 percent were "just friends" or "went out once in a while," and 2.9 percent had just met their sex partner.

2. For example, the high-risk group reported higher levels of abuse, and lower levels of parental monitoring and support, than the other two groups. 


\section{Key Readings}

Brooks-Gunn, J., \& Paikoff, R. (1997). Sexuality and developmental transitions during adolescence. In J. Schulenberg, J. L. Maggs, K. Hurrelmann, \& L. Chassin (Eds.), Health risks and developmental transitions during adolescence (pp. 190-219). Cambridge: Cambridge University Press.

This chapter provides a basic overview of adolescent sexuality from a developmental perspective and includes an extensive reference list.

Fine, M. (1988). Sexuality, schooling, and adolescent females: the missing discourse of desire. Harvard Educational Review, 58(1), 29-53.

This article is a critique of traditional sex education that has emphasized danger rather than desire.

Miller, B. C., Benson, B., \& Galbraith, K. A. (2001). Family relationships and adolescent pregnancy risk: A research synthesis. Developmental Review, 21, 1-38.

The article is a comprehensive review of research on how family factors affect adolescents' risk for pregnancy.

Moore, S., \& Rosenthal, D. (1993). Sexuality in adolescence. New York: Routledge.

This volume is an in-depth review of current research on adolescent sexual development with an international focus.

Santelli, J. S., Lindberg, L. D.. Abma, J., McNeely. C. S., \& Resnick, M. (2000). Adolescent sexual behavior: Estimates and trends from four nationally representative surveys. Family Planning Perspectives, 32, 156-165, 194.

This article is a detailed description of adolescent sexual behavior drawing from multiple national surveys conducted at different timepoints.

\section{References}

Bauman, K. E., \& Ennett, S. T. (1996). On the importance of peer influence for adolescent drug use: Commonly neglected considerations. Addiction, 91, 185-198.

Benda, B. B., \& DiBlasio, F. A. (1994). An integration of theory: Adolescent sexual contacts. Journal of Youth and Adolescence, 23(3), 403-420.

Billy, J. O. G., Brewster, K. L., \& Grady, W. R. (1994). Contextual effects on the sexual behavior of adolescent women. Journal of Marriage and the Family, 56, 387-404.

Billy, J. O. G., Rodgers, J. L., \& Udry, J. R. (1984). Adolescent sexual behavior and friendship choice. Social Forces, 662, 653-678.

Billy, J. O. G., \& Udry, J. R. (1985). The influence of male and female best friends on adolescents' sexual behavior. Adolescence, 20, 21-32.

Bingham, C. R., \& Crockett, L. J. (1996). Longitudinal adjustment patterns of boys and girls experiencing early, middle, and late sexual intercourse. Developmental Psychology, 32, 647-658.

Blum. R. W., Beuhring, T, Shew, M. L., Bearinger, L. H., Sieving, R. E., \& Resnick, M. D. (2000). The effects of race/ethnicity, income, and family structure on adolescent risk behaviors. American Journal of Public Health, 90, 1879-1884.

Brewster, K. L. (1994). Race differences in sexual activity among adolescent women: The role of neighborhood characteristics. American Sociological Review, 59, 408-424.

Brooks-Gunn, J., Duncan, G. J., Klebanov, P. K., \& Sealand, N. (1993). Do neighborhoods influence child and adolescent development? American Journal of Sociology, 99(2), 353-395.

Brooks-Gunn, J., \& Paikoff, R. (1997). Sexuality and developmental transitions during adolescence. 
In J. Schulenberg, J. L. Maggs, K. Hurrelmann, \& L. Chassin (Eds.), Health risks and developmental transitions during adolescence, pp. 190-219. Cambridge: Cambridge University Press.

Brown, P. (1983). The Swedish approach to sex education and adolescent pregnancy: Some impressions. Family Planning Perspectives, 15(2), 92-95.

Buzwell, S., \& Rosenthal, D. (1996). Constructing the sexual self: Adolescents' sexual self-perceptions and sexual risk-taking. Journal of Research on Adolescence, 6, 489-513.

Capaldi, D. M., Crosby, L., \& Stoolmiller, M. (1996). Predicting the timing of first sexual intercourse for at-risk adolescent males. Child Development, 67, 344-359.

Carpenter, L. M. (1998). From girls into women: scripts for sexuality and romance in Seventeen magazine, 1974-1994. Journal of Sex Research, 35(2), 158-168.

Centers for Disease Control and Prevention [CDC] (2000). Youth risk behavior surveillance-United States, 1999. MMWR, 49 (No. SS-5).

Chilman, C. S. (1986). Some psychosocial aspects of adolescent sexual and contraceptive behaviors in a changing American society. In J. B. Lancaster \& B. A. Hamburg (Eds.), School-age pregnancy and parenthood: biosocial dimensions (pp. 191-217). Hawthorne, NY: Aldine de Gruyter.

Coles, R., \& Stokes, G. (1985). Sex and the American teenager. New York: Harper \& Row.

Costa, F. M., Jessor, R., Donovan, J. E., \& Fortenberry, J. D. (1995). Early initiation of sexual intercourse: The influence of psychosocial unconventionality. Journal of Research on Adolescence, 5 , 93-121.

Crockett, L. J., Bingham, C. R., Chopak, J. S., \& Vicary, J. R. (1996). Timing of first sexual intercourse: The role of social control, social learning, and problem behavior. Journal of Youth and Adolescence, 25, 89-111.

Cvetkovich, G., \& Grote, B. (1980). Psychological development and the social problem of teenage pregnancy. In C. Chilman (Ed.), Adolescent pregnancy and childbearing: Findings from research (pp. 15-41). Washington, DC: US Department of Health and Human Services.

Darroch, J. E., Landry, D. J., \& Oslak, S. (1999). Age differences between sexual partners in the United States. Family Planning Perspectives, 31, 160-167.

Davis, S. M., \& Harris, M. B. (1982). Sexual knowledge, sexual interests, and sources of sexual information of rural and urban adolescents from three cultures. Adolescence, 17, 471-492.

Day, R. D. (1992). The transition to first intercourse among racially and culturally diverse youth. Journal of Marriage and the Family, 54, 749-762.

Dittus. P. J., \& Jaccard, J. (2000). The relationship of adolescent perceptions of maternal disapproval of sex and of the mother-adolescent relationship to sexual outcomes. Manuscript, Department of Psychology, State University of New York at Albany, NY.

East, P. L. (1996). The younger sisters of childbearing adolescents: Their attitudes, expectations, and behaviors. Child Development, 67, 267-282.

East, P. L., Felice, M. E., \& Morgan, M. C. (1993). Sisters' and girlfriends' sexual and childbearing behavior: effects on early adolescent girls' sexual outcomes. Journal of Marriage and the Family, 55, 953-963.

Feldman, S. S., \& Brown, N. (1993). Family influences on adolescent male sexuality: The mediational role of self-restraint. Social Development, 2, 16-35.

Feldman, S. S., Turner, R., \& Araujo, K. (1999). Interpersonal context as an influence on sexual timetables of youth: gender and ethnic effects. Journal of Research on Adolescence, 9(1), 25-52.

Fine, G. A. (1987). With the boys: Little league baseball and adolescent culture.. Chicago: University of Chicago Press.

Fine, M. (1988). Sexuality, schooling, and adolescent females: the missing discourse of desire. Harvard Educational Review, 55(1), 29-53. 
Flannery, D. J., Rowe, D. C., \& Gulley, B. L. (1993). Impacts of pubertal status, timing, and age on adolescent sexual experience and delinquency. Journal of Adolescent Research, 8, 21-40.

Forste, R. T., \& Heaton, T. B. (1988). Initiation of sexual activity among female adolescents. Youth and Society, 7.9(3), 250-268.

Gagnon, J. H. (1973). Scripts and the coordination of sexual conduct. Nebraska Symposium on Motivation, $21,27-59$.

Gagnon, J. H. (1990). The explicit and implicit use of the scripting perspective in sex research. Annual Review of Sex Research, 1, 1-43.

Garn, S. M. (1980). Continuities and change in maturational timing. In O. G. Brim \& J. Kagan (Eds.), Constancy and change in human development (pp. 113-162). Cambridge, MA: Harvard University Press.

Graber, J. A., Brooks-Gunn, J., \& Galen, B. R. (1998). Betwixt and between: Sexuality in the context of adolescent transitions. In R. Jessor (Ed.), New perspectives of adolescent risk behavior (pp. 270-316). Cambridge: Cambridge University Press.

Halpern, C. T., Udry, J. R., Campbell, B., \& Suchindran, C. (1993). Testosterone and pubertal development as predictors of sexual activity: A panel analysis of adolescent males. Psychosomatic Medicine, 55, 436-447.

Halpern-Felsher, B., Millstein, S. G., \& Ellen, M. (1996). Relationship of alcohol use and risky sexual behavior: A review and analysis. Journal of Adolescent Health, 19, 331-336.

Hamburg, B. (1986). Subsets of adolescent mothers: Developmental, biomedical, and psycho-social issues. In J. B. Lancaster \& B. A. Hamburg (Eds.), School-age pregnancy and parenthood: Biosocial dimensions (pp. 115-145). Hawthorne, NY: Aldine de Gruyter.

Hillier, L., Harrison, L., \& Bowditch, K. (1999). "Neverending love" and "blowing your load": The meanings of sex to rural youth. Sexualities, 2(1), 69-88.

Hillier, L., Harrison, L., \& Warr, D. (1997). "When you carry a condom all the boys think you want it": Negotiating competing discourses about safe sex. Journal of Adolescence, 21, 15-29.

Hogan, D. P., \& Kitagawa, E. M. (1985). The impact of social status, family structure, and neighborhood on the fertility of black adolescents. American Journal of Sociology, 90(4), 825-855.

Huston, A. C., Wartella, E., \& Donnerstein, E. $\left(1998^{\wedge}\right)$. Measuring effects of sexual content in the media: A report to the Kaiser Family Foundation. Washington, DC: Kaiser Family Foundation.

Irwin, C. E., Jr., Igra, V., Eyre, S., \& Millstein, S. (1997). Risk-taking behavior in adolescents: the paradigm. In M. S. Jacobson, J. M. Rees, N. H. Golden, \& C. E. Irwin (Eds.), Adolescent nutritional disorders: prevention and treatment (pp. 1-35). New York: New York Academy of Sciences.

Jaccard, J., Blanton, H., \& Dodge, T. (2000). Peer influence on risk behavior. Manuscript, Department of Psychology, State University of New York at Albany, NY.

Jaccard, J., Dittus, P. J., \& Gordon, V. V. (1996). Maternal correlates of adolescent sexual and contraceptive behavior. Family Planning Perspectives, 28(4), 159-185.

Jaccard, J., Dittus, P. J., \& Gordon, V. V. (1998). Parent-adolescent congruency in reports of adolescent sexual behavior and in communication about sexual behavior. Child Development, 69, 247-261.

Jacobson, K. C., \& Crockett, L. J. (2000). Parental monitoring and adolescent adjustment: An ecological perspective. Journal of Research on Adolescence, 10, 65-97.

Jessor, R., Costa, E, Jessor, S. L., \& Donovan, J. E. (1983). Time of first intercourse: A prospective study. Journal of Personality and Social Psychology, 44(3), 608-626.

Katchadourian, H. (1990). Sexuality. In S. S. Feldman \& G. R. Elliott (Eds.), At the threshold: The developing adolescent (pp. 330-351). Cambridge, MA: Harvard University Press. 
Keating, D. (1990). Adolescent thinking. In S. S. Feldman \& G. R. Elliott (Eds.), At the threshold: The developing adolescent (pp. 54-89). Cambridge, MA: Harvard University Press.

Ketterlinus, R. D., Lamb, M. E., Nitz, K., \& Elster, A. B. (1992). Adolescent nonsexual and sex-related problem behaviors. Journal of Adolescent Research, 7, 431-456.

Kowaleski-Jones, L., \& Mott, F. L. (1998). Sex, contraception and childbearing among high-risk youth: Do different factors influence males and females? Family Planning Perspectives, 30, 163-169.

Ku, L., Sonenstein, F. L., Lindberg, L. D., Bradner, C. H., Boggess, S., \& Pleck, J. H. (1998). Understanding changes in sexual activity among young metropolitan men: 1979-1995. Family Planning Perspectives, 30(6), 256-262.

Ku, L., Sonenstein, F. L., \& Pleck, J. H. (1993a). Factors influencing first intercourse for teenage men. Public Health Reports, 108(6\}, 680-694.

Ku, L., Sonenstein, F. L., \& Pleck, J. H. (1993b). Neighborhood, family and work: influences on the premarital behaviors of adolescent males. Social Forces, 72, 479-503.

Kwan, M., Greenleaf, W. J., Mann, L., Crapo, L., and Davidson, J. M. (1983). The nature of androgen action of male sexuality: A combined laboratory and self-report study in hypogonadal men. Journal of Clinical Endocrinology and. Metabolism, 57, 557-562.

Lamanna, M. A. (1999). Lining the postmodern dream: Adolescent women's discourse on relationships, sexuality, and reproduction. Journal of Family Issues, 20(2), 181-217.

Leitenberg, H., Detzer, M. J., \& Srebnik, D. (1993). Gender differences in masturbation and the relation of masturbation experience in preadolescence and/or early adolescence to sexual behavior and sexual adjustment in young adulthood. Archives of Sexual Behavior, 22(2), 87-98.

Luster, T., \& Small, S. A. (1994). Factors associated with sexual risk-taking behaviors among adolescents. Journal of Marriage and the Family, 56, 622-632.

Magnusson, D. (1988). Individual development from an interactional perspective: A longitudinal study. Hillsdale, NJ: Erlbaum.

Manlove, J., \& Terry, E. (2000). Trends in sexual activity and contraceptive use among teens (Research Brief No. 2000-03). Washington, DC: Child Trends.

Manning, W. D., Longmore, M. A., \& Giordano, P. C. (2000). The relationship context of contraceptive use at first intercourse. Family Planning Perspectives, 32(3), 104-110.

Miller, B. C., Benson, B., \& Galbraith, K. A. (2001). Family relationships and adolescent pregnancy risk: A research synthesis. Developmental Review, 21, 1-38.

Miller, B. C., \& Bingham, C. R. (1989). Family configuration in relation to the sexual behavior of female adolescents. Journal of Marriage and the Family, 51, 499-506.

Miller, B. C., McCoy, J. K., Olson, T. D., \& Wallace, C. M. (1986). Parental discipline and control attempts in relation to adolescent sexual attitudes and behavior. Journal of Marriage and the Family, 48, 503-512.

Miller, B. C., Monson, B. H., \& Norton, M. C. (1995). The effects of forced sexual intercourse on white female adolescents. Child Abuse and Neglect, 19, 1289-1301.

Miller, B. C., Norton, M. C., Curds, T, Hill, E. J., Schvaneveldt, P., \& Young, M. H. (1997). The timing of sexual intercourse among adolescents: Family, peer, and other antecedents. Youth \& Society, 29( 1), 54-83.

Miller, B. C., Norton, M. C., Fan, X., \& Chistopherson, C. R. (1998). Pubertal development, parental communication, and sexual values in relation to adolescent sexual behaviors. Journal of Early Adolescence, 18, 27-52.

Miller, B. C., \& Olson, T. D. (1988). Sexual attitudes and behavior of high school students in relation to background and contextual factors. Journal of Sex Research, 24, 194-200. 
Miller, B. C., \& Sneesby, K. (1988). Educational correlates of adolescents' sexual attitudes and behavior. Journal of Youth and Adolescence, 17, 521-530.

Miller, K. E., Sabo, D. F., Farrell, M. P., Barnes, G. M., \& Melnick, M. J. (1998). Athletic participation and sexual behavior in adolescents: the different worlds of boys and girls. Journal of Health and Social Behavior, 39, 108-123.

Miller, K. S., dark, L. F., Wendell, D. A., Levin, M. L., Gray-Ray, P., Velez. C. N., \& Webber, M. P. (1997). Adolescent heterosexual experience: A new typology. Journal of Adolescent Health, 20, 179-186.

Miller, W. B., Pasta, D. J.. MacMurray, J., Chiu, C., Wu, H., \& Comings, D. E. (1999). Dopamine receptor genes are associated with age at first sexual intercourse. Journal of Biosocial Sciences, 31, $43-54$.

Moore, S., \& Rosenthal, D. (1993). Sexuality in adolescence. New York: Routledge.

Mott. F. L.. Fondell, M. M., Hu, P. N., Kowaleski-Jones, L., \& Menaghan, E. G. (1996). The determinants of first sex by age 14 in a high-risk adolescent population. Family Planning Perspectives, 28(1), 13-18.

Newcomer, S. R, \& Udry, J. R. (1984). Mothers' influence on the sexual behavior of their teenage children. Journal of Marriage and the Family, 46, 477-485.

Newcomer, S. R, \& Udry, J. R. (1987). Parental marital status effects on adolescent sexual behavior. Journal of Marriage and the Family, 49, 235-240.

Ohannessian, C., \& Crockett, L. (1993). A longitudinal investigation of the relationship between educational investment and adolescent sexual activity. Journal of Adolescent Research, 8, $167-182$.

Orenstein (1994). School girls: Young women, self-esteem, and the confidence gap. New York: Doubleday. (Cited in Graber et al., 1998.)

Paige, K. E., \& Paige, J. M. (1985). Politics and reproductive rituals. Berkeley: University of California Press.

Paikoff, R. L. (1995). Early heterosexual debut: Situations of sexual possibility during the transition to adolescence. American Journal of Orthopsychiatry, 65(3), 389-401. Public Policy Productions (1995). Teens, sex and the schools (video).

Raffaelli, M., Bogenschneider, K., \& Flood, M. F. (1998). Parent-teen communication about sexual topics. Journal of Family Issues, 7.9(3), 316-334.

Rawlings, D., Boldero, J., \& Wiseman, F. (1995). The interaction of age with Impulsiveness and Venturesomeness in the prediction of adolescent sexual behavior. Individual Differences, 19(1), $117-120$.

Reiss, I. (1967). The social context of premarital sexual permissiveness. New York: Holt.

Richards, M. H., Crowe, P. A., Larson, R., \& Swarr, A. (1998). Developmental patterns and gender differences in the experience of peer companionship during adolescence. Child Development, 69, 154-163.

Richards, M. H., \& Larson, R. (1993). Pubertal development and the daily subjective states of young adolescents. Journal of Research on Adolescence, 3, 145-169.

Rodgers, J. L., \& Rowe, D. C. (1990). Adolescent sexual activity and mildly deviant behavior. Journal of Family Issues, 11(5), 274-293.

Rose, S., \& Frieze, I. H. (1993). Young singles' contemporary dating scripts. Sex Roles, 28, 499-509.

Rosenthal, D. A., \& Smith, M. A. (1997). Adolescent sexual timetables. Journal of Youth and Adolescence, 26(5), 619-636.

Rostosky, S. S., Wilcox, B. L., Comer Wright, M. L., \& Randall, B. A. (in press). The impact of religiosity on adolescent sexual behavior: A review of the evidence. Journal of Adolescent Research. 
Rowe, D., \& Linver, M. (1995). Smoking and addictive behaviors: Epidemiological, individual, and family factors. In J. Turner \& L. Cardon (Eds.), Behavior genetic approaches in behavioral medicine: Perspectives on individual differences (pp. 67-84). New York: Plenum.

Rowe, D. C., Rodgers, J. L, Meseck-Bushey, S., \& St. John, C. (1989a). An "epidemic" model of sexual intercourse prevalences for black and white adolescents. Social Biology, 36, 127-145.

Rowe, D. Q, Rodgers, J. L, Meseck-Bushey, S., \& St. John, C. (1989b). Sexual behavior and nonsexual deviance: A sibling study of their relationship. Developmental Psychology, 25, 61-69.

Santelli, J. S., Brener, N. D., Lowry, R., Bhatt, A., \& Zabin, L. S. (1998). Multiple sexual partners among U.S. adolescents. Family Planning Perspectives, 30, 271-275.

Satcher, D. (2001). The Surgeon General's call to action to promote sexual health and responsible sexual behavior. Retrieved from http://www.surgeongeneral.gov/library/sexualhealth/call.htm

Sherwin, B. B., Gelfand, M. M., \& Brender, W. (1985). Androgen enhances sexual motivation in females: A prospective cross-over study of sex steroid administration in the surgical menopause. Psychosomatic Medicine, 7, 339-351.

SIECUS. (1997). Male involvement in teen pregnancy. SHOP Talk (School Health Opportunities and Progress) Bulletin, 2(8).

Sieving, R., McNeely, C., \& Blum, R. (2000). Maternal expectations, mother-child connectedness, and adolescent sexual debut. Archives of Pediatrics and Adolescent Medicine, 154, 809-816.

Singh, S., \& Darroch, J. E. (1999). Trends in sexual activity among adolescent American women: 1982-1995. Family Planning Perspectives, 31(5), 212-219.

Small, S. A., \& Luster, T. (1994). Adolescent sexual activity: An ecological, risk-factor approach. Journal of Marriage and the Family, 56, 181-192.

Smith, E. A., \& Udry, J. R. (1985). Coital and non-coital sexual behaviors of white and black adolescents. American Journal of Public Health, 75(10), 1200-1203.

Smith, E. A., Udry, J. R., \& Morris, N. M. (1985). Pubertal development and friends: A biosocial explanation of adolescent sexual behavior. Journal of Health and Social Behavior, 26, $183-192$.

Smith, T. W. (1994). Attitudes toward sexual permissiveness: Trends, correlates, and behavioral connections. In A. S. Rossi (Ed.), Sexuality across the life course (pp. 63-97). Chicago: University of Chicago Press.

Sprecher, S., \& McKinney, K. (1987). Barriers in the initiation of intimate heterosexual relationships and strategies for intervention. Special issue: Intimate relationships: Some social work perspectives on love. Journal of Social Work and Human Sexuality, 5, 97-110.

Thompson, S. (1995). Going all the way: Teenage girl' tales of sex, romance, and pregnancy. New York: Hill \& Wang.

Thornton, A. (1990). The courtship process and adolescent sexuality. Journal of Family Issues, 77(3), 239-273.

Thornton, A. D., \& Camburn, D. (1987). The influence of the family on premarital sexual attitudes and behavior. Demography, 24, 323-340.

Thornton, A. D., \& Camburn, D. (1989). Religious participation and adolescent sexual behavior and attitudes. Journal of Marriage and Family, 51, 641-653.

Tolman, D. L., \& Szalacha, L. A. (1999). Dimensions of desire. Psychology of Women Quarterly, 23, 7-39.

Treboux, D., \& Busch-Rossnagel, N. A. (1990). Social network influences on adolescent sexual attitudes and behaviors. Journal of Adolescent Research, 5, 175-189.

Udry, J. R., \& Billy, J. O. G. (1987). Initiation of coitus in early adolescence. American Sociological Review, 52, 841-855. 
Udry, J. R., Billy, J. O. G., Morris, N. M., Groff, T, \& Raj, M. (1985). Serum androgenic hormones motivate sexual behavior in adolescent boys. Fertility and Sterility, 45, 90-94.

Udry, J. R., \& Campbell, B. C. (1994). Getting started on sexual behavior. In A. S. Rossi (Ed.), Sexuality across the life course (pp. 187-207). Chicago: University of Chicago Press.

Udry, J. R., Talbert, L. M., \& Morris, N. M. (1986). Biosocial foundations for adolescent female sexuality. Demography, 23, 217-230.

Upchurch, D. M., Aneshensel, C. S., Sucoff, C. A., \& Levy-Storms, L. (1999). Neighborhood and family contexts of adolescent sexual activity. Journal of Marriage and the Family, 61, 920-933.

Weinstein, M., \& Thornton, A. (1989). Mother-child relations and adolescent sexual attitudes and behaviors. Demography, 26(4), 563-577.

Whitbeck, L., Conger, R., \& Kao, M. (1993). The influence of parental support, depressed affect, and peers on the sexual behaviors of adolescent girls. Journal of Family Issues, 14(2), 261-278.

Whitbeck, L. B., Conger, R. D., Simons, R. L., \& Kao, M. (1993). Minor deviant behaviors and adolescent sexual activity. Youth \& Society, 25(1), 24-37.

Whitbeck, L., Hoyt, D., Miller, M., \& Kao, M. (1992). Parental support, depressed affect, and sexual experiences among adolescents. Youth and Society, 24(2), 166-177.

Whitbeck, L. B., Simons, R. L., \& Kao, M. Y. (1994). The effects of divorced mothers' dating behaviors and sexual attitudes on the sexual attitudes and behaviors of their adolescent children. Journal of Marriage and the Family, 56, 615-621.

Whitbeck, L. B., Yoder, K. A., Hoyt, D. R., \& Conger, R. D. (1999). Early adolescent sexual activity: a developmental study. Journal of Marriage and the Family, 61, 934-946.

Whiting, J. W, Burbank, V. K., \& Ratner, M. S. (1986). The duration of maidenhood across cultures. In J. B. Lancaster \& B. A. Hamburg (Eds.), School-age pregnancy and parenthood: Biosocial dimensions (pp. 273-302). Hawthorne, NY: Aldine de Gruyter.

Widmer, E. D. (1997). Influence of older siblings on initiation of sexual intercourse. Journal of Marriage and the Family, 59, 928-938.

Wyatt, G. E., \& Riederle, M. H. (1994). Reconceptualizing issues that affect women's sexual decision-making and sexual functioning. Psychology of Women Quarterly, 18, 611-625. 